\title{
Experimental test of threaded steel rods glued-in hardwood with epoxy
}

\author{
D. Otero, J. Estévez, E. Martín \& J. A. Vázquez \\ Department of Construction Technology, \\ Advanced Technical School of Architecture, University of A Coruña, \\ Spain
}

\begin{abstract}
This paper summarizes test results of an experimental study on threaded steel rods epoxied into structural hardwood members.

Two test campaigns were carried out. In the first one 36 test specimens of Tali sawn timber (Erythropleum ivorense) with threaded steel rods were tested. Tests arose from the need to evaluate the behaviour of this type of joint because of its use in the construction of hollow bars spatial mesh of laminated timber.

Three anchorage lengths and two bar diameters were tested. Moreover, two different thicknesses of the glue line, $1 \mathrm{~mm}$ and $3 \mathrm{~mm}$, were investigated.

In order to complement the first tests a new experimental study with 180 test specimens was carried out. In the second tests, double-sided pull-out tests of Spanish chestnut timber saw specimens were performed. Small diameter threaded steel rods $(8,10$ y $12 \mathrm{~mm}$ ) quality 8.8 (yield stress $640 \mathrm{MPa}$ ) were used.

In the paper the most significant results of both test campaigns are summarized, as well as the comparison with the existing design formulae for of this type of union.

Keywords: joint design, glued-in rods, adhesives for wood, hollow bars, spatial mesh, destructive testing.
\end{abstract}

\section{Introduction}

Our team has been researching for a long time on space frames. Timber space frames are a particular aspect of this research. Special attention has been paid to the use of hollow sections in the making of this type of structure. Several patents are the outcome of our pioneering work in this field. 
A Coruña University commissioned the design of the roof structure for a sports hall on the Zapateira Campus. The project became the first built application of the research. The main aim was to span over this hall with a stackable modular space frame made up with hollow timber sections (Figure 1).

Achieving an efficient transmission of loads in the bar node is one of the main problems of this type of structures. The use of hollow sections increases even more this problem.

The design solution for the bar end connection with the steel node involves gluing solid timber sections of Elondo or Tali (Erythrophleum ivorense). Threaded steel rods (either 24 or $27 \mathrm{~mm}$ diameter) are then embedded into the sawn timber and glued with a two component Hilti HIT-RE 500 epoxy resin (epoxidic bisphenol $\mathrm{A} / \mathrm{F}$ and poliamid alifatic bases, both with inorganic filling) (Figure 2).

Given the influence of the efficiency of this connector on the behaviour of the structure, we decided to supplement the theoretical calculations with experimental analysis. This is the main aim of this article.

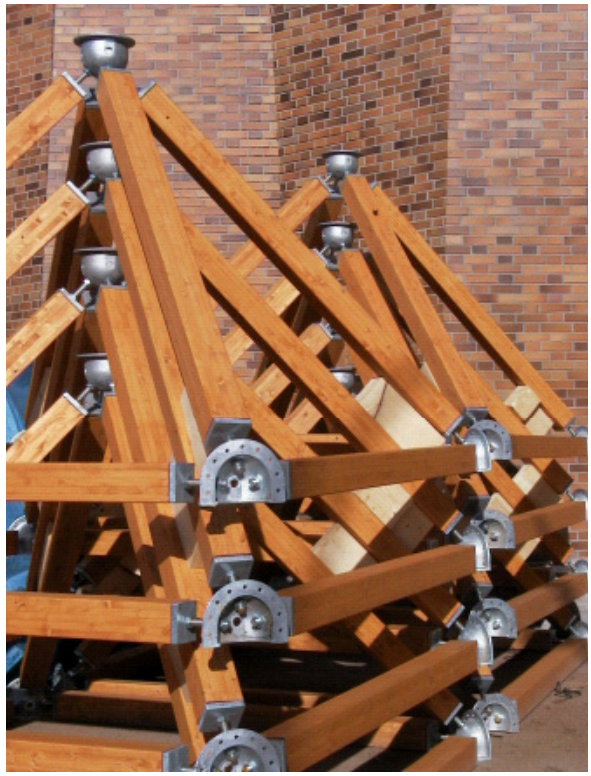

Figure 1: Stacked space frame modules.

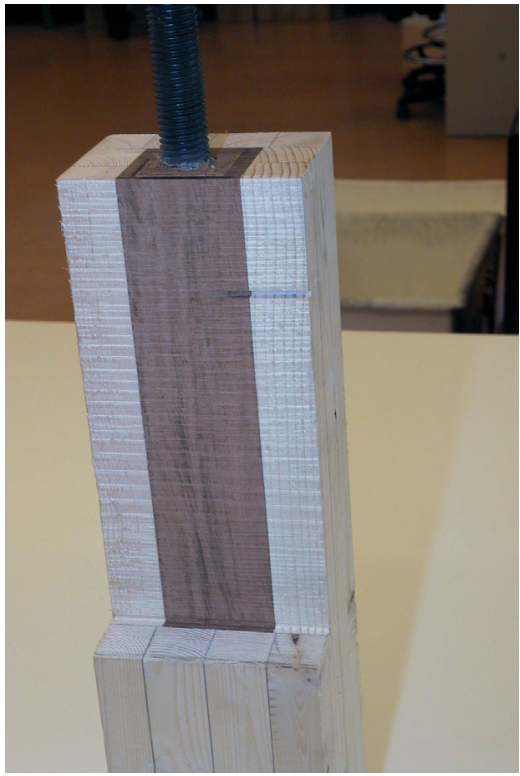

Figure 2: Cut of the end of the bar to show how the Elondo block is glued into the hollow bars of glulam.

\section{Theoretical research of the joint strength}

The only rules references for the calculation of this type of unions appears collected as informative annex in the Eurocódigo 5, according to: 


$$
\begin{aligned}
& \mathrm{R}_{\mathrm{ax}, \mathrm{k}}=\pi \cdot \mathrm{d}_{\mathrm{equ}} \cdot \mathrm{L}_{\mathrm{g}} \cdot \mathrm{f}_{\mathrm{vk}} \\
& \mathrm{f}_{\mathrm{vk}}=0,8 \cdot 10^{-3} \cdot \rho_{\mathrm{k}}^{1,5} \cdot \mathrm{d}^{-0,2}
\end{aligned}
$$

For rods glued in grain direction, with:

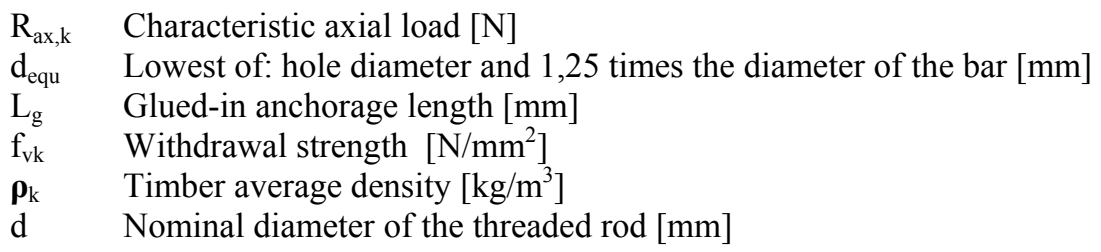

In the results section we will show that experimental values result significantly lower than estimated by Eurocode formulae values. A number of other design equations were used to compare results. Several references that provide equations of design have been consulted, showing so much dispersion in criteria as in results. For the purposes of comparison the formulae provided by pioneering studies of $\mathrm{H}$. Riberholt $[1,2]$ was used in this case, as following:

$$
\begin{aligned}
& \mathrm{R}_{\mathrm{ax}, \mathrm{k}}=\mathrm{f}_{\mathrm{ws}} \cdot \rho_{\mathrm{k}} \cdot \mathrm{d} \cdot \sqrt{\mathrm{L}_{\mathrm{g}}} ; \text { to } \mathrm{L}_{\mathrm{g}} \geq 200 \mathrm{~mm} \\
& \mathrm{R}_{\mathrm{ax}, \mathrm{k}}=\mathrm{f}_{\mathrm{wl}} \cdot \rho_{\mathrm{k}} \cdot \mathrm{d} \cdot \mathrm{L}_{\mathrm{g}} ; \text { to } \mathrm{L}_{\mathrm{g}}<200 \mathrm{~mm}
\end{aligned}
$$

with:

$$
\begin{array}{ll}
\mathrm{R}_{\mathrm{ax}, \mathrm{k}} & \text { Characteristic axial load }[\mathrm{N}] \\
\mathrm{f}_{\mathrm{ws}} & \begin{array}{l}
\text { Strength parameter }\left[\mathrm{N} / \mathrm{mm}^{1,5}\right] \\
\end{array} \\
\mathrm{f}_{\mathrm{wl}} & \begin{array}{l}
\text { Epoxi type adhesives take the value of } 0,520 \\
\text { Strength parameter [N/mm }
\end{array} \\
& \text { Epoxi type adhesives take the value of } 0,037 \\
\boldsymbol{\rho}_{\mathrm{k}} & \text { Timber average density }\left[\mathrm{kg} / \mathrm{m}^{3}\right] \\
\mathrm{d} & \text { Nominal diameter of the threaded rod }[\mathrm{mm}] \\
\mathrm{L}_{\mathrm{g}} & \text { Glued-in anchorage length }[\mathrm{mm}]
\end{array}
$$

\section{Materials characteristics and test devices.}

In the first experimental campaign one-sided-push compression tests were carried out over specimens made of sawn timber of Elondo o Tali (Erythrophelum ivorense) with glued threaded steel rods. Rods were glued only in one end of the timber specimen. This solution was directly related to the endelements development for hollow glulam bars. It conditioned, in some ways, the geometric configuration of the specimens and the diameter of the threaded rods utilized. 
Sawn timber blocks, with threaded rods glued-in, were glued into the hollow bars subsequently. Cross-section of the blocks was determined from the characteristics of hollow bars. In accordance with this dimensions, cross-section of test specimens were $75 \times 75$ and $90 \times 90 \mathrm{~mm}$.

For each one of the geometric configurations three anchorage lengths, 200, 250 and $300 \mathrm{~mm}$, were studied. These lengths were inside the compatible levels with the execution of the hollow bars of the mesh.

Timber of test specimens achieved an average density of $911 \mathrm{~kg} / \mathrm{m}^{3}$ and a characteristic density of $856.36 \mathrm{~kg} / \mathrm{m}^{3}$, which corresponds to the $5^{\text {th }}$ percentile. Galvanized threaded steel bars grade 8.8 (with a yield strength of fy=640 N/mm and minimum tensile strength of $\mathrm{fu}=800 \mathrm{~N} / \mathrm{mm}^{2}$ ) have been used. Rod surface was not treated before bonding, because this is not a usual practice in normal construction.

Rods with nominal diameters of 24 and $27 \mathrm{~mm}$ were used. It address with rod diameters used in the construction of the space frame hollow sections. Nominal rod diameters were dependent on the constructive conditioning of the steel nodes of the mesh too. For that reason they did not agree with values suggested in Eurocode 5.

The adhesive was the same as the one used in the construction of the space frame: Hilti HIT-RE 500. Joints glued with two adhesive thicknesses (1 and 3 $\mathrm{mm}$.) have been studied.

The combination of these geometric variables gave as a result 12 types of different test specimens, whose characteristics are summarized in the table 1.

Table 1: Geometric characteristics of the specimens tested in the first experimental campaign.

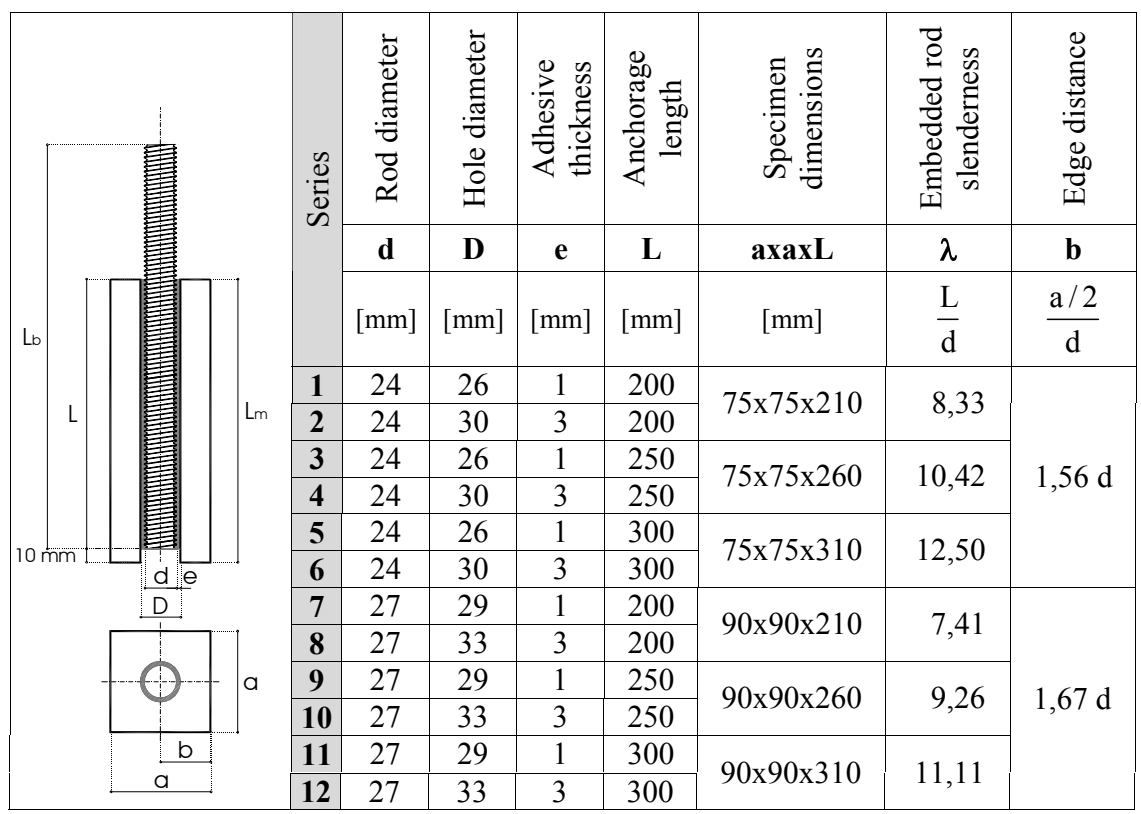


The test sample was longitudinally drilled with an auger drill to the centre of the section. The drill hole went across all the specimen length. The lower end of the sample was then closed with a $10 \mathrm{~mm}$ thick piece of elastic material (elastic stopper). The adhesive was blown to fill the drilled cavity with a mixing gun. Afterwards, the threaded bars were inserted manually by continuous pressing and rotating. The particular design of the test sample has been chosen in order to enable the test to be carried out in an INSTRON mod. $8805,1000 \mathrm{kN}$ one-sided pull-compression universal dynamic press (Figure 3). The elastic stopper at the lower end of the test sample allows the threaded bar to glide down when it reaches its load limit. For test reliability purposes, the rod exposed end was fastened to the load cell by means of a nut. Also, the test sample was placed on the base plate with a $3 \mathrm{~mm}$ thick neoprene sheet in between, in order to take the imperfections of the support.

A picture of the test device is shown in figure 3.

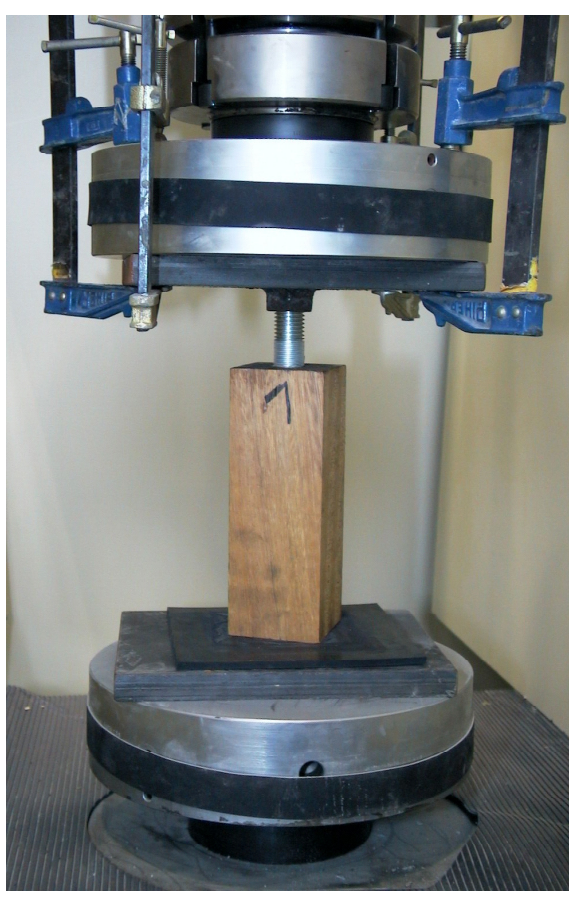

Figure 3: Test device used in the first experimental campaign.

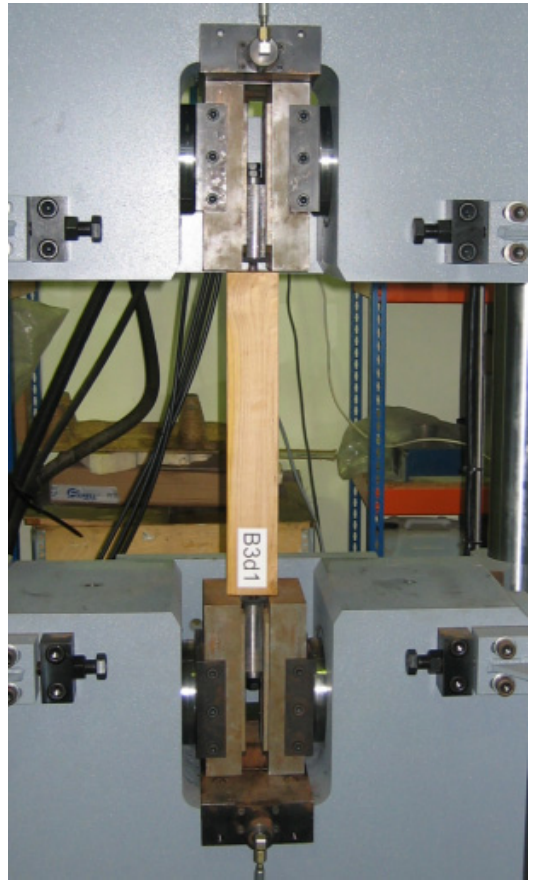

Figure 4: Test device used in the second experimental campaign.

Like it is shown in results section, experimental results were lower than theoretical values that were calculated with design formulae. In order to complement first tests a new experimental study with 135 test specimens were carried out. In the second tests double-sided pull-out test of Spanish chestnut (Castanea sativa) timber saw specimens were performed. Test specimens were 
made of Spanish chestnut untreated timber. The cross-section dimensions of the different test specimens were six times the width of the bars diameter. Specimens' lengths were three times the rod anchorage length.

Glulam is the timber that has been utilized generally for this kind of joints, and the greatest number of the existing formulations are based on it. Because chestnut timber was a kind of hardwood with an average density very similar to glulam it was chosen for the second experimental campaign.

Timber of test specimens achieved an average density of $567.28 \mathrm{~kg} / \mathrm{m}^{3}$ and a characteristic density $474.02 \mathrm{~kg} / \mathrm{m}^{3}$ (corresponding $5^{\text {th }}$ percentile). Calculating in design formulae a value of $475 \mathrm{~kg} / \mathrm{m}^{3}$ was used.

Small diameter threaded steel rods $(8,10$ and $12 \mathrm{~mm}$ ) quality 8.8 (yield stress $640 \mathrm{MPa}$ ) were used. Five different anchorage lengths were tested, from $60 \mathrm{~mm}$. until $180 \mathrm{~mm}$. three epoxy systems (Hilti, Sika and Locktite) in glueline thickness of $1 \mathrm{~mm}$ were investigated. Attending to the geometric parameters, there were fifteen different types of test specimens.

Geometric characteristics of the specimens tested in the second experimental campaign are summarized in the table 2 .

As is shown by figure 4, the specimens were tested on double-side-tensile device in the second experimental campaign. To this end, blind drills were carried out in both ends of the specimen and the threaded steel rods were glued inside them. For that, as in the previous case, the adhesive was blown to fill the drilled cavity with a mixing gun and threaded bars were inserted manually by continuous pressing and rotating.

Both of the experimental studies were carried out increasing the load with a constant displacement. The failure value was reached in $5 \pm 2$ minutes.

\section{Results}

The INSTRON test machine has an electronic device that controls the displacement of the load cell. It also interprets the results with a computer system that gives the digitalized relationship between load, displacement and test time-length. The graphic representation of results showed correlation between stiffness of the three systems adhesives which were used in the second experimental campaign.

More repeated failure modes were shear failure in timber, and timber splitting. For specimens with the lowest diameter the main sample failure was tensile failure in steel threaded rods.

Using Eurocode 5 and Riberholt formulae the theoretical values for each series were calculated. Both experimental and theoretical values were plotted to assess correlation between them.

One representative example of each experimental campaign is shown in the next figures. Solid lines in the first one (Figure 6) represent theoretical values for Elondo specimens, with a characteristic density of $865 \mathrm{~kg} / \mathrm{m}^{3}$, a rod diameter of $24 \mathrm{~mm}$ and a glueline thickness of $1 \mathrm{~mm}$, with anchorage lengths from 150 to 350 $\mathrm{mm}$. Crosses show experimental results, corresponding series 1, 3 and 5 . 
Table 2: Geometric characteristics of the specimens tested in the second experimental campaign.

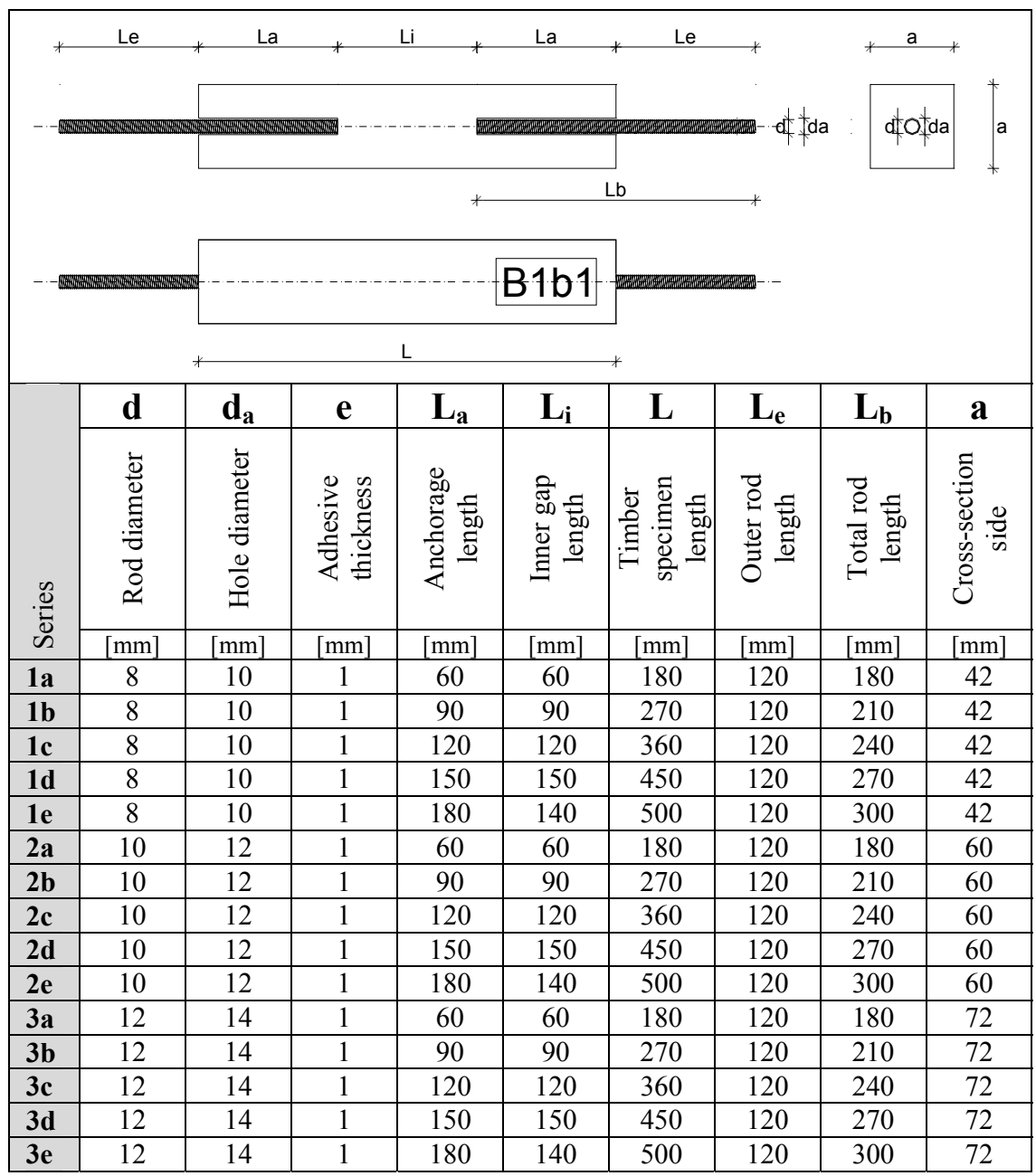

In view of that theoretical values were referred on characteristic values, experimental results were significantly lower than theoretical ones.

These results could be due to the high density of the Elondo timber compared with the glulam density (traditionally used in this kind of joints), and to the small dimensions of the cross-section of the specimens. This cross-section was dependent on the hollow bars dimensions, which lead to an edge distance lower than literature suggested ones. 


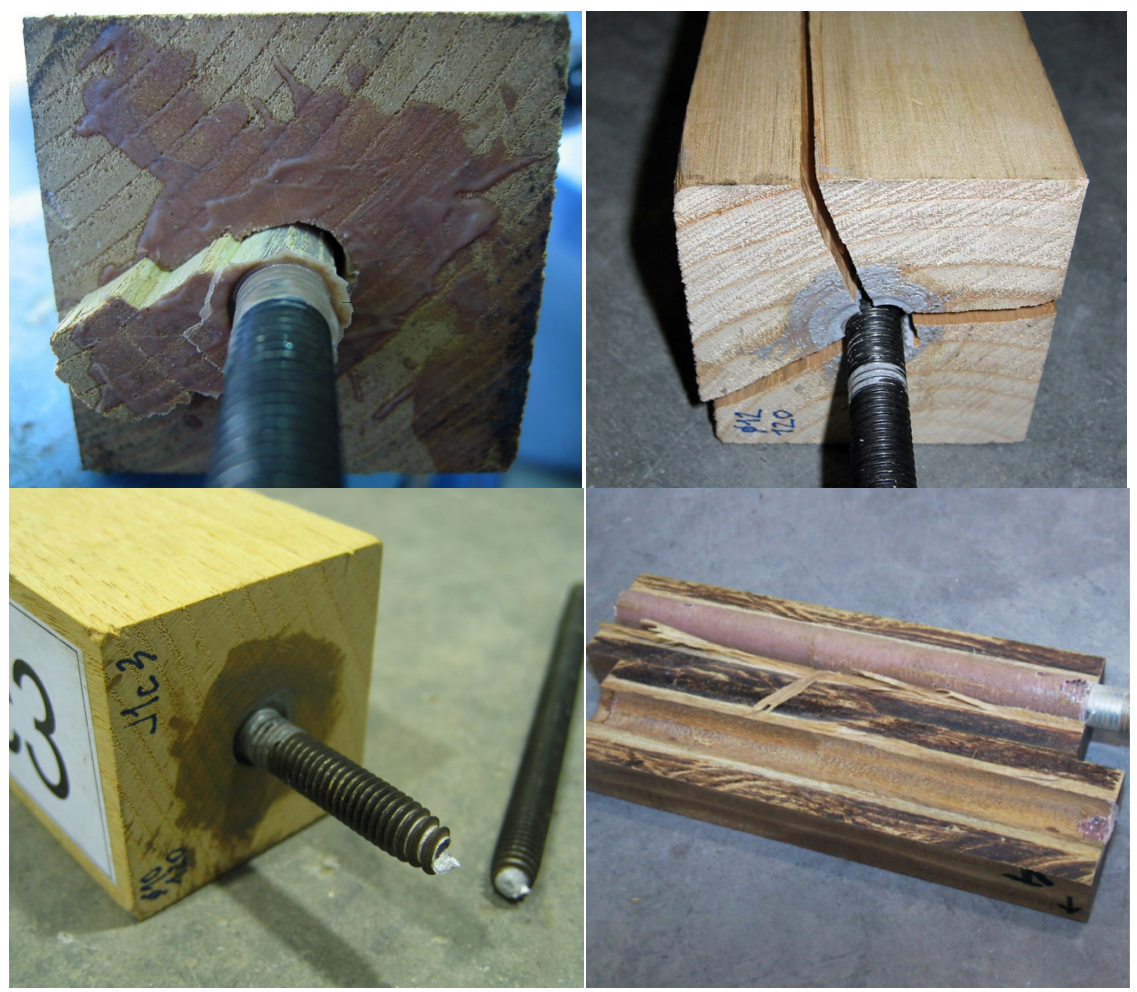

Figure 5: Main failure modes: shear failure in timber, timber splitting, tensile failure in steel threaded rods and shear failure in the timber close interface timber/adhesive.

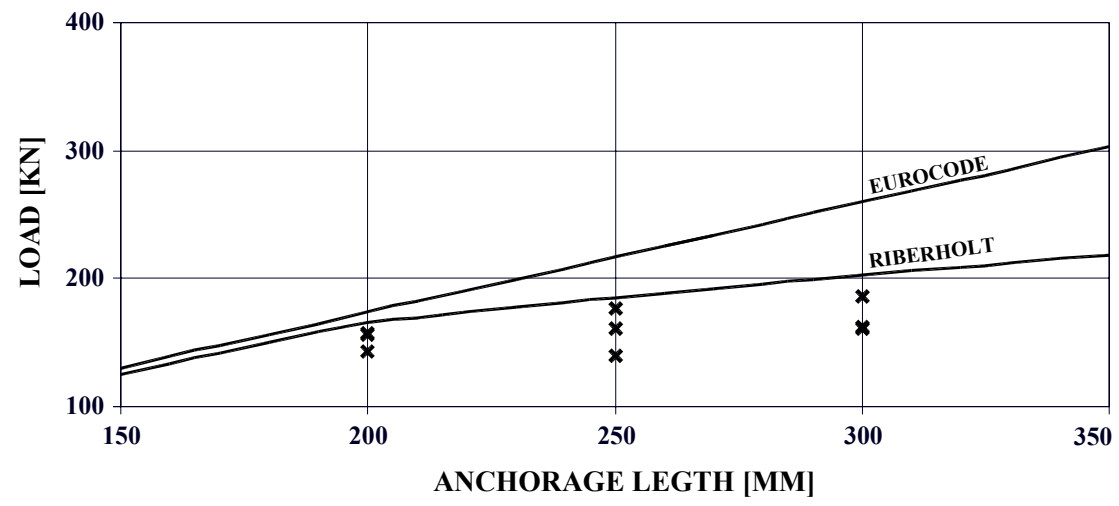

Figure 6: Experimental results and theoretical values, according to Eurocode and Riberholt formulae, to Elondo specimens with threaded steel rods of diameter $24 \mathrm{~mm}$ and a glueline thickness of $1 \mathrm{~mm}$. 
To chestnut specimen's theoretical values to a characteristic density of 475 $\mathrm{kg} / \mathrm{m}^{3}$, a rod diameter of $12 \mathrm{~mm}$ and a glueline thickness of $1 \mathrm{~mm}$, with anchorage lengths from 40 to $220 \mathrm{~mm}$, are plotted in Figure 7. Crosses show experimental results, corresponding series 1, 3 and 5. It squares with test series $3 \mathrm{a}, 3 \mathrm{~b}, 3 \mathrm{c}, 3 \mathrm{~d}$, and $3 \mathrm{e}$, which failure loads are represented with crosses.

These results are more akin to theoretical values, taking into account that formulae are referred to characteristic values $\left(5^{\text {th }}\right.$ percentile).

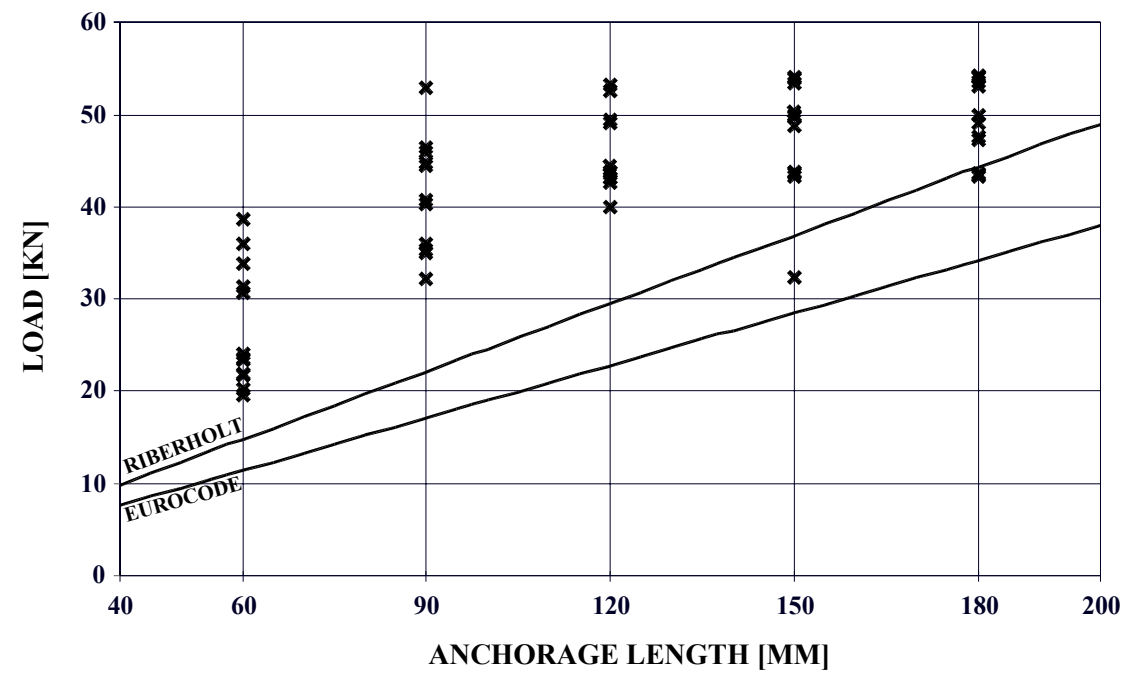

Figure 7: Experimental results and theoretical values, according to Eurocode and Riberholt formulae, to chestnut specimens with threaded steel rods of diameter $12 \mathrm{~mm}$ and a glueline thickness of $1 \mathrm{~mm}$.

Results show that more works needs to be done in joints made with rods glued in high density hardwood timber. This works will allow one to adapt formulae to this material characteristic and will allow one to study the influence of edge distance. Our research team is working about it.

\section{Conclusions}

Several series of samples have been tested. The test samples were made with threaded steel rods glued into two different kinds of hardwood timber. The rods were glued using three different systems of two-component epoxy-base adhesive.

The test samples were made varying the following parameters: glued anchorage length, rod diameter and glue thickness

The obtained results have been compared to existing theoretical formulations. The comparison showed a significant difference between the theoretical predictions and the test results when high density hardwood is used. 


\section{Acknowledgment}

This research is sponsored by the Ministry of Science and Technology through research project titled "UNIONES METÁLICAS ENCOLADAS CON ADHESIVOS EN BARRAS DE MADERA" (Glued Anchored Timber Joints). The financial support is gratefully acknowledged.

\section{References}

[1] Riberholt H., Glue Bolts in Glulam, Department of Structural Engineering. Technical University of Denmark. Serie R, No 210, 1986.

[2] Riberholt H., Glued bolts in glulam-Proposal for CIB Code. CIB-W18 Meeting. Parksville, Vancouver Island, Canada. Paper 21-7-2, 1988.

[3] Broughton J.G., Hutchinson A.R, Pull-out behaviour of steel rods bonded into timber, Materials and Structures. ASCE. AUG. 2001. VOL. 127 No. 8, 2001.

[4] Estévez Cimadevila, F.J.; Vázquez Rodríguez, J.A. \& Otero Chans, M.D, Diseño y dimensionado del nudo extremo de una barra hueca de madera laminada, CIMAD04. $1^{\circ}$ Congreso Ibérico A Madeira na Construçao. Universidade do Minho. Guimaraes. Portugal. Pag 689-698, 2004.

[5] Estévez Cimadevila, J. \& Vázquez Rodríguez, J.A, Spatial truss of hollow bars made of laminated timber supported by walls of reinforced masonry, Journal of the International Association for Shell and Spatial Structures. Vol. 45 (2004) n.1. April n.144. IASS. ISSN: 0304-3622, 2004.

[6] Estévez Cimadevila, J.\& Vázquez Rodríguez, J.A, Edificio sportivo a La Coruña, Spagna, Construire in Laterizio, n.102. Año XVII. NoviembreDiciembre 2004.Grupo Editoriales Faenza Edotrice S.p.A. Faenza (Ra). 